\title{
Geriatrik açıdan ameliyat öncesi ve sonrası beklenen ve beklenmeyen sorunlar; irdeleme ve tedavi
}

\author{
Geriatric expected and unexpected problems before and after surgery; \\ scrutiny and treatment
}

\author{
Banu Özulu Türkmen
}

SBÜ Prof. Dr. Cemil Taşçıoğlu Şehir Hastanesi, İç Hastalıkları Kliniği Geriatri Bölümü, İstanbul

\begin{abstract}
Kalça kırıkları yaşlı hastalarda yaygın olarak görülmektedir ve önemli bir maluliyet, morbidite ve mortalite nedenidir. Hastaların çoğu kırılgan ve kırılganlık öncesi hasta grubundadır. Kalça kırı̆̆ı, bazen altta yatan birincil ciddi bir hastalığa ya da uygunsuz ilaç kullanımına ikincil düşme sonrasında da gelişebilir. Öte yandan hastalarda takipleri sırasında venöz tromboemboli, ağrı, enfeksiyon, deliryum, hipervolemi, malnütrisyon ve basınç ülserleri gibi çok sayıda ciddi sorunlar gelişebilir. Bu sebeple, kalça kırığına yaklaşımda hızlı cerrahi tedavi esas olmakla beraber ameliyat öncesi ve sonrası süreçlerde çok alanlı yaklaşımın önemli olabileceği düşünülmektedir. Yazımızda kalça kırığı ile hastaneye yatan geriatrik hastalarda ameliyat öncesi süreçte temel yaklaşım ve cerrahi sonrası dahili sorunların yönetimini güncel kılavuzlar ve literatür eşliğinde özetlemeye çalıştık.
\end{abstract}

Anahtar sözcülkler: yaşlı hasta; kalça kırığı; osteoporoz; kırılganlık
Hip fractures are common in older patients and associated with disability, significant morbidity and mortality. Most of the patients are frail and pre-frail. Hip fractures may sometimes develop after a fall secondary to an underlying primary serious cause or inappropriate medication use; on the other hand, many serious problems such as venous thromboembolism, pain, infection, delirium, hypervolemia, malnutrition, pressure ulcers may develop during follow-up. Although rapid surgical treatment is essential for the approach to hip fracture, it is considered that a multidisciplinary approach can be important in pre-and postoperative processes. In this article, basic approach in the preoperative process and the management of postoperative problems in geriatric hospitalized patients with hip fracture are summarised inline with the current guidelines and available literature.

Key words: older patient; hip fracture; osteoporosis; frailty

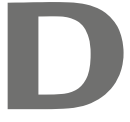

ünya genelinde, özellikle de gelişmiş ülkelerde, hijyen kurallarına uyulması sonucu daha sağlıklı yaşam stili, artmış sağlık hizmetleri, gelişen teknolojinin etkisiyle birlikte beklenen yaşam süresi ve yaşlı nüfus giderek artmaktadır. 1960 civarında Avrupa ülkelerinde doğumda beklenen yaşam süresi 69 yaş iken 2010 yılında bu 80'e yükselmiştir ve ilerleyen yıllarda daha da yükselmesi beklenmektedir. ${ }^{[1]}$ Beklenen yaşam süresinde artış ile beraber geriatrik yaştaki birey sayısı ve toplam nüfusa oranı da zamanla artmıştır. Yaşlanma süreci tüm vücut sistemlerinde çok sayıda biyolojik mekanizmayı tetiklemektedir ve ön görülmesi bazen güç olan ilerleyici süreçler ile azalan fonksiyonel rezervler fizyolojik ve patolojik strese tahammül etmeyi zorlaştırarak kötü sonlanımlara yatkınlık oluşturmaktadır.[2] Düşme ve kalça kırıkları geriatrik hastalar arasında önemli morbidite, mortalite ve maluliyet sebepleri arasındadır. Kalça kırıklarının yaklaşık \%95'inin düşme kaynaklı olduğu belirtilmektedir. Düşmeler, geriatrik hastalarda sıklıkla gözlenmekte olup $\geq 65$ yaş bireylerin \%25'i her yıl en az bir kez düşme tariflemektedir. Bununla birlikte, düşmelerin yaklaşık \%20'si ise kalça kırığı gibi ciddi travma ile sonuçlanmaktadır. Özellikle $\geq 85$ yaş popülasyon düşmelere ve düşmelere bağlı travmatik hasara yatkındır. ${ }^{[3,4]}$ Yaşlı hastalarda kalça kırığının tedavisinde hızlı cerrahi tedavi esas olmakla beraber eşlik eden ek hastalıklar da göz önüne alındığında çok alanlı yaklaşımın önemli olabileceği düşünülmektedir.

- İletişim adresi: Uzm. Dr. Banu Özulu Türkmen, SBÜ Prof. Dr. Cemil Taşçıŏglu Şehir Hastanesi, İç Hastalıkları Kliniği Geriatri Kliniği, Darülaceze Caddesi No: 27 Okmeydanı, Şişli, İstanbul Tel: 0533 - 0297822 E-posta: dr_banu84@hotmail.com 


\section{GERIATRIIK KALÇA KIRIĞI HASTALARINDA AMELIYAT ÖNCESI SÜREÇ}

Kalça kırığı ile başvuran hastaların önemli bir kısmı kırılganlık öncesi (pre-frail) ve kırılgan (frail) hasta grubundadır. Kırılganlık, yaşlanma ile birlikte fizyolojik rezerv ve işlevlerde azalmaya bağlı olarak gelişen, günlük veya akut stres yapıcılarla başa çıkma kabiliyetinin olumsuz etkilenmesi ile ortaya çıkan kötü sonuçlara yatkınlık artışı ile sonuçlanan durum şeklinde tanımlanabilir. Kırılganlık, düşme ve komplikasyonları açısından riski artıran bir durum olmakla beraber iyileşme sürecini de olumsuz etkilemektedir. ${ }^{[5]}$

Düşmenin birincil sebebi altta yatan enfeksiyonlar, inme, senkop, miyokard infarktüsü gibi ciddi durumlar olabilir. Bu sebeple kalça kırığı açısından değerlendirilirken; düşme anamnezinin iyi alınması, yol açabilecek olası tıbbi sorun açısından da değerlendirilmesi ve gereğinde nedene yönelik tedavisinin başlanarak taburculuk sonrası dönem için de gerekli önerilerin planlanması önemlidir. ${ }^{[6]}$

Düşme öyküsü irdelenirken hastanın kalça kırığı haricinde travmatik hasar durumu hızlı bir şekilde değerlendirilmeli, şüphe dâhilinde uygun görüntülemeler yapılmalıdır. Mümkünse her hastaya elektrokardiyografi (EKG), akciğer grafisi, hemogram, C-reaktif protein (CRP), tam idrar tahlili, kan şekeri, karaciğer fonksiyon testleri ve böbrek fonksiyon testlerini içeren temel biyokimyasal testler, pıhtılaşma testleri (özellikle varfarin kullanan hastalarda), üriner enfeksiyon şüphesi varsa idrar kültürü, akut koroner sendrom şüphesi varsa kardiyak enzim ve gereğinde takibi istenmelidir. ${ }^{[6-8]}$ Ayrıca bazal tiroid fonksiyon değerleri (hipo/hipertiroidi açısından), vitamin B12, folat ve $\mathrm{D}$ vitamini düzeylerinin istenmesi kalça kırığı olan yaşı ıastalarda önemlidir. ${ }^{[6,7]}$ Tüm dünyayı etkisi altına alan koronavirüs hastalığı 2019 (COVID19) pandemisine bağı olarak da özellikle yaşlı hastalarda düşmelerin görülebileceği ve bu hastaların kalça kırıkları ile başvurabilecekleri unutulmamalı, şüphe dahilinde hastalar bu yönde de değerlendirilmeli ve tetkik edilmelidir. ${ }^{[9]}$ Yatan her yaşlı hasta mutlaka çoklu ve uygunsuz ilaç kullanımı yönünden değerlendirilmelidir. Polifarmasi, basit bir açıklama ile çok sayıda ilacın birlikte kullanılması olarak ifade edilebilir; değişik tanımlamalara göre 5-10 ve üzeri ilacın beraber kullanılma durumu için kullanılmaktadır ancak çalışmalarda sıklıkla tanım olarak $\geq 5$ ilaç kullanımını belirtmek için tercih edilmektedir. ${ }^{[10]}$ Polifarmasi değerlendirilirken bitkisel ekstrelerin de göz önünde bulundurulması önemlidir. Eşlik eden hastalıkları göz önüne alındığında yaşı hastalarda polifarmasi gerçekten gerekli olabilir ancak ilaç yan etkileri açısından bağımsız bir risk faktörüdür. Birçok ilaç düşme riskini artırabilmekte, tekrarlayan düşmeler açısından birer risk faktörü olabilmektedir. ${ }^{[10,11]}$ illaç anamnezinin ayrıntılı olarak alınması ve gereğinde manipülasyonların yapılması kalça kırığı hastalarında sıklıkla gözlenen deliryumu önlemek açısından da önemlidir.

Ülkemizde yaşlıda uygunsuz ilaç kullanımı ve polifarmasinin önlenmesine yönelik olarak hazırlanıp yayımlanan TIME kriterlerinde düşme riski olanlarda vitamin D idame tedavisinin aralıklı yüksek dozda (300,000 iU) kullanımı, ortostatik hipotansiyonu olanlarda üroselektif olmayan alfa 1 kullanımı, yüksek antikolinerjik etkili ilaçlar (trisiklik antidepresanlar, klorpromazin, tioridazin, klozapin, olanzapin, hiyosin, oral oksibutinin), birinci nesil antihistaminikler (feniramin, klorfeniramin, hidroksizin, siproheptadin, dimenhidrinat, difenhidramin, meklizin, paroksetin vb.) gibi ilaçların artmış düşme riski ile ilişkili olduğu vurgulanmış olup yaşam beklentisi düşük, düşme riski yüksek olan hastalarda sık kan basıncı ve kan şekeri kontrolü önerilmiştir. Öte yandan deliryum riski olanlarda ise amitriptilin, paroksetin, disiklomin, L-hiyosiyamin, tioridazin, klorpromazin, klozapin, olanzapin yüksek antikolinerjik etkili ilaçların, üriner antimuskariniklerin, özellikle birinci nesil difenhidramin, siproheptadin, feniramin gibi $\mathrm{H} 1$ reseptör blokerleri ile, $\mathrm{H} 2$ reseptör blokerlerinin kognitif kötüleşme riskine karşın kullanımının uygun olmadığı belirtilmiştir. Ayrıca, sıklıkla ameliyat sonrası ağrı tedavisine tercih edilen meperidinden artmış deliryum riski nedeniyle kaçınılması gerektiği vurgulanmıştır. ${ }^{[12]}$ Kalça kırığı olan hastaların olabildiğince hızlı cerrahi tedavilerinin uygulanması ağrıyı ve kan kaybını azaltabilir ve hareketin sağlanması, mortalitenin azaltılmasını sağlayacağı yönünde yayınlar mevcuttur. Bununla birlikte hemodinamiyi etkileyen, ciddi, kararsız sepsis, kardiyovasküler tablolar gibi durumlar ameliyat öncesi dönemde ele alınmalı ve cerrahi zamanlama için hastanın durumuna göre karar verilmelidir. ${ }^{[6,13]}$

\section{TAKIPTE KARŞILABILECEK TEMEL SORUNLAR VE YAKLAŞIMLAR}

\section{Venöz Tromboemboli Profilaksisi}

Venöz tromboemboli riski ortopedi ve travmatoloji alanındaki cerrahi süreçte ve hareketsizlik ile beraber artmış olup kalça kırığı ile yatan hastaların uygun antikoagülasyon tedaviyi alması önemlidir. Bu sebeple mekanik profilaksi ile birlikte (havalı yatak, varis çorabı) cerrahi öncesi dönemde hastalar antikoagülasyon açısından değerlendirilmelidir. Ameliyattan önceki dönemde en az 12 saat önce düşük molekül ağırlıklı heparin (DMAH) başlanmalı, en az 10-14 gün, tercihen cerrahi sonrası 35 güne kadar devam edilmelidir. ${ }^{[8,14]}$ 


\section{Analjezi}

Kalça kırığı olan hastalarda ağrı sık olup artmış deliryum riski ve bozulmuş fonksiyonellik ile ilişkilidir. Kırıkların takip ve tedavisinde en temel analjezik parasetamol olup tercihen oral yoldan kullanılmalıdır. Bununla birlikte uzamış kullanımları ile karaciğer toksisitesi riski mevcuttur. Steroid olmayan anti enflamatuvar ilaçlar da güçlü analjeziklerdir ancak böbrek yetmezliği, hiperpotasemi, gastrointestinal toksisite gibi olası yan etkileri nedeniyle rutin olarak kullanılmamalı, gereğinde çok dikkatli uygulanmalıdır. ${ }^{[6,7]}$ Ağrı kontrolü sağlanamayan hastalarda opioidler alternatif olabilir. Tüm opiodler yaşılılarda 2 kat kadar güçlü olup, bu gruptaki tüm ilaçların çok düşük dozlarda dahi solunum depresyonu yapabileceği göz önüne alınarak zaruri hallerde, karaciğer ve böbrek fonksiyonları değerlendirilerek kontrollü olarak uygulanmalıdır. ${ }^{[15]}$ Periferal sinir bloklarının da ağrı yönetiminde yararlı olabileceği belirtilmiştir.

\section{Enfeksiyonlara Yönelik Profilaksi}

Kalça kırı̆̆ı olan hastalara antimikrobiyal profilaksi gerekmektedir. Birinci kuşak sefalosporin (sefazolin sodyum) ilk tercihtir. Beta laktam grubu antibiyotiklere karşı aşırı duyarlıı̆̆ı olan hastalarda klindamisin veya vankomisin düşünülebilir. Cerrahi sahada enfeksiyon varlığında ise gram negatifleri kapsayacak şekilde antibiyotik spektrumu genişletilmelidir. ${ }^{[16]}$

\section{Kalça Kırığı Hastalarında Deliryum}

Deliryum, sıklıkla yaşlı ve hastanede yatan hastalarda gözlenen, bilişsellikte, dikkat ve odaklanmada akut bozulma ile kendini gösteren ve genellikle geceleri kötüleşen bir tablodur. ${ }^{[7]}$ Deliryum kalça kırı̆̆ı hastalarının \%28-61'ini etkilemektedir ve uzamış hastane yatışları, fonksiyonelliği kazanmada gecikme, yüksek maliyet gibi kötü klinik sonlanımlarla ilişkilidir. ${ }^{[18]}$ Deliryumun, mevcut demans ve depresyon, ciddi hastalık tablosu, görme ve işitme bozukluğu gibi durumlarda sıklığı daha fazladır ve de uygunsuz ilaç kullanımı, fiziksel kısıtlayıcılar, dehidratasyon, kötü nütrisyonel durum, enfeksiyon, elektrolit bozuklukları ile tetiklenebilmektedir. ${ }^{[19]}$ Deliryum günler içerisinde düzelebileceği gibi kimi zaman daha uzun süreli olabilir, haftalar boyunca izlenebilir. Bazı hastalarda ajitasyon, bazılarında ise bitkinlik ve fazla yatışmış durum hakimdir. Tabloya halüsinasyonlar, uyku düzeninde değişme, motor bozukluklar eşlik edebilir. Hareketlerde yavaşlamanın, bitkinliğin ön planda olduğu deliryum tipi hipoaktif deliryum olarak adlandırılmaktadır ve tanı konması zor olabilmektedir. ${ }^{[17,20]}$ Ayrıca demansif hastalarda deliryum tanısı mevcut temel bilişsel durumun da kötü olmasından kaynaklı olarak güç olabilmektedir. Bu yüzden, hızlı kötüleşme varlığında hastalar deliryum açısından değerlendirilmelidir. ${ }^{[21]}$ Deliryum tanısında DSM V Kriterleri, 4 AT testi gibi testlerden yararlanılabilse de tanıda klinik esastır. ${ }^{[19,20]}$

Deliryum, kalça kırığı hastalarında önlenebilir ve/ veya uygun yaklaşımlarla şiddeti azaltılabilir bir klinik tablodur. Hastaların ağrılarının azaltılması, kabızlığın engellenmesi, işitme ve görmede en uygun durumu sağlamak (işitme cihazı-gözlük kullanıyorsa hastanede yatarken de kullanmaları yönünde teşvik etmek), erken hareket vermek, deliryum riski ile ilişkili ilaçlardan mümkünse kaçınmak, ideal beslenme ve hidrasyonu sağlamak önemlidir. Ayrıca deliryum riski olan hastalarda oda değişimi yapmaktan mümkün olduğunca kaçınılması gerekmektedir. ${ }^{[6,22]}$ Hastane yatışı ve ileri yaş, deliryum açısından risk olmakla beraber altta yatan önemli bir patolojinin de habercisi olabileceği daima göz önünde bulundurulmalıdır. Klinik şüphe varlığında ve özellikle cerrahi sonrası 1 . günde ortaya çıkan tablolarda ileri yönde değerlendirme yapılması gerekmektedir. Bu hastalarda kardiyopulmoner patolojiler ve enfeksiyonlar yönünde hızlı değerlendirme önemlidir. ${ }^{[6]}$ Hiperaktif deliryum tablosu varlığında mevcut tedavi yönetimi zor olabileceği ve tedavi reddi olabileceği için tıbbi olarak tedavi edilmesi gerekebilmektedir. Haloperidol ve ketiapin yaşlı hastalarda ön planda düşünülebilecek ilaçlardır, tüm ilaçlar düşük doz başlanmalı, kademeli olarak artırılmalıdır. Ilaçlar hiçbir zaman birincil çözüm değil, zorunluluk olarak ele alınmalıdır. Haloperidol oral ya da parenteral kullanılabilir. Parenteral uygulamalarında özellikle parkinsonizmi olan hastalarda ise ekstrapiramidal yan etkilerin ciddi düzeyde olabileceği unutulmamalıdır. Atipik antipsikotiklerden risperidon ve olanzapin klinik gereklilik durumunda tercih edilebilmekle beraber ekstra piramidal yan etki riski fazladır. Bununla birlikte olanzapinin sedasyon riski haloperidole göre daha düşüktür. ${ }^{[23]}$ Tüm antipsikotik ilaçların QT düzeyinde uzama yapabileceği bilinmeli, gereğinde bu açıdan takip edilmelidir. Ketiapin, ekstra piramidal yan etki riski yüksek olan hastalarda tercih edilebilir. ${ }^{[20,24]}$ Eşlik eden COVID19 durumunda ise ketiapin mortalite riskini belirgin olarak artırabileceği için gereğinde psikiyatri desteği ile tedavi yeniden ele alınmalıdır.

Benzodiazepinlerin ise alkol yoksunluk sendromu hariç deliryumda kullanım endikasyonu yoktur, solunum depresyon riski yüksek olduğu için yaşlılarda zaruri haller haricinde kaçınılmalıdır. ${ }^{[20]}$

\section{Kalça Kırığı Hastalarında Nütrisyonel Yönetim}

Avrupa Klinik Nütrisyon ve Metabolizma Derneği (ESPEN) tanımına göre malnütrisyon, oral alımdaki yetersizlik ve beslenmedeki düzensizliğe ikinci olarak 
gelişen vücut yağ kitlesinde azalma ve hücre kitlesindeki bozulma ile ortaya çıkan fiziksel ve mental fonksiyonlarda azalma ve kliniğin kötüleşmesi olarak tanımlanmaktadır. ${ }^{[25]}$ Malnütrisyon, kalça kırığı hastalarında sıklıkla gözlenmekte olup, kırık sonrasında fonksiyonel iyileşmeyi geciktirerek mortalite üzerine risk faktörü olabilmektedir.

Kalça kırığı ile takip edilen hastalar, başvuru anında kötü besleniyor olabilir, bununla birlikte yatış süresinde de oral alımları bozularak nütrisyonel risk artabilir. Bu sebeple kalça kırığı ile yatışı yapılan her hastanın beslenme durumu değerlendirilmelidir. ${ }^{[26]}$ Nütrisyonel değerlendirmede farklı metotlardan yararlanılabilmekle beraber Nütrisyonel Risk Skoru-2002 (NRS-2002) yatan hastalarda kolayca uygulanabilir ve sıklıkla tercih edilen yol gösterici bir testtir. ${ }^{[27]}$ Besin tüketim kaydı hastaların oral alımlarını değerlendirme konusunda yol gösterici olabilir. Bir kontrendikasyon yoksa hastaların diş protezlerini kullanmaları, oral alımı azaltabilecek ilaçlar ve koşullar açısından değerlendirilmesi nütrisyon yönetiminde yararlı olabilir. Ameliyat öncesi oral alımı azaltabilecek koşulların olabildiğince en az düzeyde tutulması önerilmektedir. Hastalarının birçoğunun fiziksel açıdan formda olmadığı göz önüne alınarak disfaji değerlendirilmesi ve gereğinde diyetlerinin disfajiye uygun şekilde düzenlenmeleri yapılmalıdır. ${ }^{[6]}$ Nütrisyonel değerlendirmede çok alanlı yaklaşım yararlı olabilmektedir, bu sebeple diyetisyenin de dâhil olduğu nütrisyon ekibi tarafından değerlendirilerek uygun tedavi gereğinde başlanmalıdır. ESPEN 2018 geriatrik hastalarda nütrisyon kılavuzunda, nütrisyonel durumdan bağımsız olarak, ameliyat sonrası dönemde her hastaya oral nütrisyonel destek başlanmasının komplikasyon riskini azaltabileceğini öne sürerek önerilmiştir ve başlanması durumunda en az 1 ay süreyle kullanımını tavsiye edilmiştir. ${ }^{[28]}$

\section{Sıvı Dengesi ve Kabızlık Takibi}

Hastalar hipervolemiye yatkın oldukları için aldığı ve çıkardığı sıvı takipleri önemlidir. Bu sebeple hareketsiz de oldukları için hastalara kısa süreliğine mesane sondası takılarak takip edilmelidir. Mesane sondası cerrahi sonrası 24 saat içinde çıkartılmalıdır. Gereğinden uzun süreli mesane sondası kullanmanın deliryum ve üriner enfeksiyon riskini artırdığı unutulmamalıdır. ${ }^{[17]}$ Kabızlık, yaşlılarda özellikle de hareketsizlik durumlarında sıklıkla gözlenmekte, hastanın hayat kalitesini olumsuz yönde etkilemektedir. Ayrıca deliryum risk faktörleri arasında da olduğu için kalça kırığı hastalarında kabızı̆ı̆ın önlenmesi çok önemlidir. Kullanılan opioidler de kabızlık riskini artırabilmektedir, bu sebeple hastalarda konstipasyonun takibi önemlidir. Şiddetli kabızlık durumlarında fekal impakt ve cerrahi sonrası ileus da ayrıcı tanılara dâhil edilmekle beraber, akut acil tablo düşünülmeyen durumlarda hastaya ilk olarak uyarıcı laksatifler başlanabilir ancak, hasta hâlihazırda kullanmakta iken kabızlık devam ediyorsa osmotik laksatif ilave edilmesi düşünülebilir. ${ }^{[7]}$

\section{Tansiyon Takibi ve Ortostatizm}

Kalça kırığı ile servise yatan hastaların günlük en az iki kez kan basıncı kontrolleri yapılmalıdır, olası bir hipotansiyon ya da hipertansiyon durumunda ilaçları gözden geçirilmeli ve tedavi düzenlenmesi açısından değerlendirilmelidir. Ortostatizm ise yaşlı hastaların önemli bir kısmını etkilemekte olup başlı başına bir düşme risk faktörü sayılmaktadır. Uzun süre hareketsiz olarak takip edilen bu grup hastaların harekete kavuşması sonrasında ortostatik hipotansiyon riskleri artmaktadır. Bu durum tekrarlayan düşme ve düşme korkusu açısından risk faktörü olabileceği için mümkünse tüm hastalar hareket kazandıktan sonra ortostatizm açısından değerlendirilmeli ve takip edilmelidir. Saptanması durumunda ise etiyoloji değerlendirilerek (uygunsuz ilaç, dehidratasyon, hipovolemi) tedavi düzenlenmelidir. ${ }^{[6]}$

\section{Kalça Kırığı Hastalarında Anemi}

Hastalar, cerrahi süreçte anemik ise kan transfüzyonu gerekebilir. Birçok hastada semptomatik anemi ya da kardiyak sorun yok ise $8 \mathrm{~g} / \mathrm{dl}$ ye kadar kan verilmeyebileceği belirtilmektedir. Bununla birlikte kardiyak sorunu olanlarda ve/veya serebral veya pulmoner fonksiyonlarda bozulma var ise hedef hemoglobin düzeyleri 9-10 g/dl olmalıdır. Transfüzyon kararı hemoglobinde düşüş düzeyi, yeni gelişen baş dönmesi, halsizlik gibi semptomlar değerlendirilerek bireysel olarak verilmelidir. ${ }^{[6,7]}$ Kalça kırığında transfüzyon hedefleri halen tartışmalıdır. Yakın zamanlı çalışmalarda cerrahi süreçte demir destek tedavisinin de yararlı olabileceğini gösteren çalışmalar mevcuttur. ${ }^{[29]}$

\section{Basınç Ülserine Yönelik Önlemler ve Tedavi}

Basınç ülserleri kalça kırı̆̆ı olan hastalarda sıklıkla gözlenmekte olup sıklığı \%36 oranında belirtilmiştir. Bası yarası gelişimi ile ilgili risk faktörleri birçok çalışmada değerlendirilmiştir. İleri yaş, kötü zihinsel durum, diyabet, başvuru öncesi kötü fonksiyonel durum, düşük hemoglobin ve cerrahi süreçte fazla miktarda kan kaybı olması risk faktörleri olarak gösterilmiştir. ${ }^{[30]}$ Basınç ülserlerinin temel olarak evrelendirilmesi Tablo 1'de gösterilmiştir. [31]

Basınç ülserinin gelişmesi hastanın hayat kalitesini anlamlı ölçüde bozacağı için önlenmesi önemlidir, özel olarak tasarlanmış yataklardan yararlanılabilir. 
Tablo 1. Basınç ülserlerinin evrelemesi ${ }^{[31]}$
Evre 1
Cilt bütünlüğü bozulmamış, basmakla solmayan eritem.
Evre 2 Büllöz oluşum veya dermisin parsiyel kalınlık kaybı \pm enfeksiyon.
Evre 3 Tam kat kaybı.
Subkutan yağ dokusu görülebilir, destrüksiyon kasa kadar ilerlemiştir \pm enfeksiyon.
Yara cepler veya görülebilir.
Evre $4 \quad K e m i k$, tendon veya kasların etkilendiği tam kat doku kaybı.
Eskar görülebilir.
Cepleşme, tünelleşme sık.
Evrelendirilemeyen Gerçek derinlik bilinemez, kaplayan sarı nekrotik doku ve/veya eskar +
Derin doku hasarı Mor veya bordo renginde lokalize alan, içi genelde kanla dolu vezikül ağrılı, sert, sıcak ya da soğuk olabilir.

Tablo 2. Bası yarası gelişmesi durumunda temel yaklaşım ${ }^{[32]}$

\begin{tabular}{ll}
\hline Ağrı kontrolü & Bazı hastalarda ağrı şiddetli olabilir, değerlendirme ve takibi önemlidir. \\
& Ağıı olması durumunda enfeksiyon ve iskemi açısından değerlendirilmelidir. \\
& Ağrı genelde sistemik tedaviden yarar görmektedir. \\
Enfeksiyon & $\begin{array}{l}\text { Bakteriyel biyofilm varlığı yara iyileşmesini bozabilir. } \\
\text { Derin ülserleri olan hastalar enfeksiyon ve osteomiyelit açısından değerlendirilmeli ve uygun antibiyoterapi ile tedavi } \\
\text { edilmelidir. }\end{array}$ \\
Nütrisyon & $\begin{array}{l}\text { Basınç ülserlerinin oluşmasını engellemek için de tedavi için de uygun besin desteği çok önemlidir. } \\
\text { Protein alım hedefi genel olarak 1,2-1,5 g/kg olarak belirlense de büyük basınç yaralarının varlığında ihtiyaç daha fazla } \\
\text { olabilmektedir. }\end{array}$ \\
Pozisyon & Düzenli pozisyon değişimi ve uygun ekipman (yatak, nevresim, yastık) kullanımı yara gelişimi önlemede de oluşan \\
& yaranın ilerlemesini engellemede de etkindir.
\end{tabular}

Hareketsiz oldukları dönemde hastaların pozisyonları belli aralıklarla değiştirilmeli, basıncın dağıımı sağlanmalı, hastalarda hipotansiyona karşı dikkatli olmalı, yeterli nütrisyonel destek sağlanmalı, basınç ülserleri açısından hastalar günlük olarak değerlendirilmeli, deri temiz ve kuru tutulmalıdır (inkontinansı olan hastalarda bez değişimi aralıkları uzun süreli olmamalı). Cilt bakımları yapılırken $\mathrm{pH}$ dengeli ürünler tercih edilmeli, sert masajdan ve sıcak sudan kaçınılmalı, hastalar olabildiğince hızlı hareketine kavuşturulmalıdır. Bası yarası gelişmesi durumunda ise hastalarda temel yaklaşımlar Tablo 2'de özetlenmiştir. ${ }^{[32]}$

Sonuç olarak, kalça kırığı özellikle yaşı popülasyonda önemli bir mortalite ve morbidite nedenidir. Hasta popülasyonunu sıklıkla kırılgan geriatrik hastalar olup çok alanlı yaklaşım önemlidir. Taburculuk aşamasına gelen hastaların tekrarlayan düşmelere yönelik tedbirler konusunda bilgilendirilmeleri, osteoporoz tedavilerinin planlanmaları, nütrisyonel açıdan değerlendirilerek yönlendirilmeleri, uygunsuz ilaç kullanımına karşı bilinçlendirmeleri, çevresel düzenlemelerin yapılması, fizyoterapilerinin planlanmaları, gereğinde sosyal hizmet desteğinden yararlanılması uzun dönem morbidite ve mortalite üzerine yarar sağlayacaktır. Bu sebeple kalça kırığı ile servise yatan hastalara çok alanlı yaklaşım önemlidir.

\section{KAYNAKLAR}

1. Brown GC. Living too long: the current focus of medical research on increasing the quantity, rather than the quality, of life is damaging our health and harming the economy. EMBO Rep 2015;16(2):137-41. Crossref

2. Wolfe JD, Wolfe NK, Rich MW. Perioperative care of the geriatric patient for noncardiac surgery. Clin Cardiol 2020;43(2):127-36. Crossref

3. Bergen G, Stevens MR, Burns ER. Falls and Fall Injuries Among Adults Aged $\geq 65$ Years - United States, 2014. MMWR Morb Mortal Wkly Rep 2016;65(37):993-8. Crossref

4. Centers for Disease Control and Prevention (CDC). Home and Recreational Safety: Important Facts about Falls. https:// www.cdc.gov/homeandrecreationalsafety/falls/adultfalls. html

5. Waltson JD. Frailty. In: Schmader KE, Givens J, editors. Uptodate; 2020. https://www.uptodate.com/contents/ frailty

6. Ranhoff AH, Saltvedt I, Frihagen F, Raeder J, Maini S, Sletvold O. Interdisciplinary care of hip fractures: Orthogeriatric models, alternative models, interdisciplinary teamwork. Best Pract Res Clin Rheumatol 2019;33(2):205-26. Crossref

7. Morrison RS, Siu AL. Hip fracture in adults: Epidemiology and medical management. In: Schmader KE, Kunins L, editors. Uptodate; 2020. https://www.uptodate.com/contents/hipfracture-in-adults-epidemiology-and-medical-management 
8. Ikpeze TC, Mohney S, Elfar JC. Initial Preoperative Management of Geriatric Hip Fractures. Geriatr Orthop Surg Rehabil 2017;8(1):64-6. Crossref

9. Norman RE, Stall NM, Sinha SK. Typically Atypical: COVID-19 Presenting as a Fall in an Older Adult. J Am Geriatr Soc 2020;68(7): E36-7. Crossref

10. Rochon AP. Drug prescribing for older adults. In: Schmader KE, Givens J, editors. Uptodate; 2020. https://www.uptodate. com/contents/drug-prescribing-for-older-adults/print

11. Ferner RE, Aronson JK. Communicating information about drug safety. BMJ 2006;333(7559):143-5. Crossref

12. Bahat $G$, Ilhan B, Erdogan $T$, Halil M, Savas S, Ulger Z, Akyuz F, Bilge AK, Cakir S, Demirkan K, Erelel M, Guler K, Hanagasi H, Izgi B, Kadioglu A, Karan A, Kulaksizoglu IB, Mert A, Ozturk S, Satman I, Sever MS, Tukek T, Uresin Y, Yalcin O, Yesilot N, Oren MM, Karan MA. Turkish inappropriate medication use in the elderly (TIME) criteria to improve prescribing in older adults: TIME-to-STOP/TIME-to-START. Eur Geriatr Med 2020;11(3):491-8. Crossref

13. Pincus D, Ravi B, Wasserstein D, Huang A, Paterson JM, Nathens AB, Kreder HJ, Jenkinson RJ, Wodchis WP. Association Between Wait Time and 30-Day Mortality in Adults Undergoing Hip Fracture Surgery. JAMA 2017;318(20):1994-2003. Crossref

14. Siu CW, Sun NCH, Lau TW, Yiu KH, Leung F, Tse HF. Preoperative cardiac risk assessment in geriatric patients with hip fractures: an orthopedic surgeons' perspective. Osteoporos Int 2010;21(Suppl 4):587-91. Crossref

15. Barnett $\mathrm{S}$. Anesthesia for the older adult. In: Uptodate. Joshi GP, Nussmeier NA, editors. Uptodate; 2019. https://www. uptodate.com/contents/anesthesia-for-the-older-adult/print

16. Anderson DJ, Sexton DJ. Antimicrobial prophylaxis for prevention of surgical site infection in adults. In: Harris A, Mitty J, editors. Uptodate;2019. https://www.uptodate.com/contents/antimicrobialprophylaxis-for-prevention-of-surgical-site-infection-in-adults/ print

17. Oh ES, Fong TG, Hshieh TT, Inouye SK. Delirium in older persons: Advances in diagnosis and treatment. JAMA 2017;318(12):1161-74. Crossref

18. Hshieh TT, Yue J, Oh E, Puelle M, Dowal S, Travison T, Inouye SK. Effectiveness of multicomponent nonpharmacological delirium interventions: a meta-analysis. JAMA Intern Med 2015;175(4):512-20. Crossref

19. Inouye SK, Growdon M, Fong T. Delirium (Chap. 47). In: Halter JB, Ouslander JG, Tinetti ME, Studenski S, High KP, Asthana S, Supiano MA, Ritchie C, editors. Hazzard's Geriatric Medicine and Gerontology, 7th ed. New York: The McGraw Hill Companies; 2016. p.712.

20. Francis J, Young GB. Diagnosis of delirium and confusional states. In: Aminoff MJ, Schmader KE, Wilterdink JL, editors. Uptodate; 2020. https://www.uptodate.com/contents/ diagnosis-of-delirium-and-confusional-states
21. Morandi A, Bellelli G. Delirium superimposed on dementia. Eur Geriatr Med 2020;11(1):53-62. Crossref

22. Soiza RL, Myint PK. The Scottish Intercollegiate Guidelines Network (SIGN)157: Guidelines on risk reduction and management of delirium. Medicina (Kaunas) 2019;55(8):491. Crossref

23. Marcantonio ER. Delirium in Hospitalized Older Adults. N Engl J Med 2017;377:1456-66. Crossref

24. Lee S, Gottlieb M, Mulhausen P, Wilbur J, Reisinger HS, Han $\mathrm{JH}$, Carnahan R. Recognition, prevention, and treatment of delirium in emergency department: An evidence-based narrative review. Am J Emerg Med 2020;38(2):349-57. Crossref

25. Cederholm T, Barazzoni R, Austin P, Ballmer P, Biolo G, Bischoff SC, Compher C, Correia I, Higashiguchi T, Holst M, Jensen GL, Malone A, Muscaritoli M, Nyulasi I, Pirlich M, Rothenberg E, Schindler K, Schneider SM, de van der Schueren MA, Sieber C, Valentini L, Yu JC, Van Gossum A, Singer P. ESPEN guidelines on definitions and terminology of clinical nutrition. Clin Nutr 2017;36(1):49-64. Crossref

26. Malafarina $V$, Reginster $J Y$, Cabrerizo $S$, Bruyère $O$, Kanis $J A$, Martinez JA, Zulet MA. Nutritional status and nutritional treatment are related to outcomes and mortality in older adults with hip fracture. Nutrients 2018;10(5):555. Crossref

27. Zhou J, Wang M, Wang $\mathrm{H}$, Chi Q. Comparison of two nutrition assessment tools in surgical elderly inpatients in Northern China. Nutr J 2015;14:68. Crossref

28. Volkert D, Beck AM, Cederholm T, Cruz-Jentoft A, Goisser S, Hooper L, Kiesswetter E, Maggio M, Raynaud-Simon A, Sieber CC, Sobotka L, van Asselt D, Wirth R, Bischoff SC. ESPEN guideline on clinical nutrition and hydration in geriatrics. Clin Nutr 2019;38(1):10-47. Crossref

29. Smith A, Moon T, Pak T, Park B, Urman RD. Preoperative anemia treatment with intravenous iron in patients undergoing major orthopedic surgery: A Systematic review. Geriatr Orthop Surg Rehabil 2020;11:2151459320935094. Crossref

30. Baumgarten $M$, Margolis DJ, Orwig DL, Shardell MD, Hawkes WG, Langenberg P, Palmer MH, Jones PS, McArdle PF, Sterling R, Kinosian BP, Rich SE, Sowinski J, Magaziner J. Pressure ulcers in elderly patients with hip fracture across the continuum of care. J Am Geriatr Soc 2009;57(5):863-70. Crossref

31. National Pressure Injury Advisory Panel. NPIAP Pressure Injury Stages. Available at: https://cdn.ymaws.com/npiap. $\mathrm{com} /$ resource/resmgr/online_store/npiap_pressure_injury_ stages.pdf

32. Berlowitz D. Clinical staging and management of pressureinduced skin and soft tissue injury. In: Berman RS, Schmader KE, Collins KA, editors. Uptodate; 2020. https://www. uptodate.com/contents/clinical-staging-and-managementof-pressure-induced-skin-and-soft-tissue-injury 